\title{
台湾在住諸族の人類学的研究
}

\section{福建系，広東系漢族ならびにタイヤル族， アミ族について}

\author{
欠田早陷 \\ 兵庫医科大学第二解剖学教室
}

\begin{abstract}
要約 台湾の種族特性に関して, 単一の研究者による数種族の生体計測值を比較した。漢 族は高山族（タイヤル，アミ族）上り計測学的にまさり，漢族内では出身の省をことにした 福建系が広東系より体格が小さく，アミ族はタイヤル族より身体の大きいととが指摘され た。
\end{abstract}

台湾には漢族および数種の高山族とが居住し ている。乙れら諸種族の類縁関係を明らかにす る目的をむって, 形質人類学的な研究は台湾大 学医学院解剖学科を中心として発展してきた。 台湾高山族や漢民族の身体的な特異性む 1950 年代に金関（1952）によって，すでに明らかに されている。その後は高山族に関する報告を多 く見るが，いずれの報告も各種族の地方的な一 集団のみを資料にしたすので, やや綜合性に欠 ける傾问があった。今回はての弱点を補うため に, 同一研究者による複数の種族の成績を基礎 として相互の関係を明らかにしようとするあの である。資料はこの目的のために 1969 年, 故 小浜基次名誉教授が収集したものである。

\section{研 究方法}

生体計測は Martin によった。計測項目とそ の指数はつぎのとおりである。

体部：身長，下肢長（右腸骨前上栜高），身區 幹長〔(胸骨上縁高 $)-($ 右腸骨前上棘高 $)]$, 上 肢長〔(右肩峰高) - (右中指尖高 $)$, 肩峰巾, 骨盤巾, 比下肢長, 比軀幹長, 比上肢長, 比肩 峰巾, 比骨盤门。

頭部：頭長, 頭门, 頭耳高, 頭長巾指数, 頭 長高指数, 頭巾高指数。
顔部：煩骨弓巾, 下顎角巾 (Gleitzirkel 飞よ り Gonion を下方より測定), 容貌顔面高, 形 態顔面高 I, 眼内角巾, 口巾, 鼻高 I (Supraorbitale より), II (鼻背最凹点より), 鼻巾, 耳長, 耳巾, 頭顔指数, 下顎角指数, 容貌顔面 指数, 形態顔面指数 I, 鼻高巾指数 I, II, 耳 長巾指数。

平均値の 差の検定は, $Q=\left(M_{1}-M_{2}\right) / \sqrt{{m_{1}}^{2}}$ $\overline{+m_{2}{ }^{2}}$ によった。 $Q$ の值が 3.0 以上（有意水準 $\alpha \doteqdot 0.3 \%$ 以下）のときは, $\left\lceil M_{1}\right.$ は $M_{2}$ よりも明 らかに大きい」といい, また 2.0 以上（有意水 準 $\alpha=4.5 \%$ 以下）のときは，「かなり大きい」 と表現した。

集団の類似度の判定は平均偏差比法 $\frac{1}{S}-\Sigma$ $\frac{\left|M_{1}-M_{2}\right|}{\sigma_{1}}$ によった。体部, 頭部, 顔部それ ぞれの平均偏差比を算出して, 数量的に類似度 を検定し，てれらをさらに総合して種族間の近 似性を推定した。

漢族は出身省に従って広東系漢族ならびに福 建系漢族に分類し，それぞれ台北市内之高雄市 内，および擪東県で，またタイヤル族は台湾北 中部に执いて，アミ族は花蓮市近郊で調査し た。

資料の年令は 20-60 才を基準とした。集計 に用いた人員構成は次の如くである。 
男 性女 性

人員数 平均年令 人員数 平均年令

$\begin{array}{lrrrr}\text { 福 建 人 } 224 & 34.6 & 86 & 36.4 \\ \text { 広 東 人 } 104 & 38.3 & 35 & 32.5 \\ \text { タイヤル族 } & 32 & 37.5 & 51 & 37.5 \\ \text { アミ 族 } & 30 & 40.3 & 28 & 39.0\end{array}$

比較は平埔族（劉, 1960), 広東人（山下， 1940), 福建人 (忽那, 柳井, 1943), タイヤル族 (張, 1960), アミ族（黄, 1960）（陳, 1960）の 成績を用いた。

調 查 成 績

\section{I）体部について}

1) 身長 (Tab. 1, Fig. 1)

漢族男性の広東人 $(166.34 \mathrm{~cm})$ は福建人
(164. $57 \mathrm{~cm})$ よりかなり大きい。アミ族 $(162.44 \mathrm{~cm})$ はタイヤル族 $(160.39 \mathrm{~cm})$ より かなり大きく, 両者とも漢族よりかなり小さ い。アミ族と広東人, タイヤル族と漢族との差 は明らかである。女性ですとれと同様の傾向を うかがいうるが，アミ族 $(152.00 \mathrm{~cm})$ とタイ ヤル族 $(152.66 \mathrm{~cm})$ とは近似している。

平埔族男性 $(164.15 \mathrm{~cm})$ は漢族男性に, 平 埔族女性 $(152.43 \mathrm{~cm})$ はむしろタイヤル，ア ミ族に近似している。

\section{2) 下肢長, 比下肢長 (Tab. 2, Fig. 1)}

下肢長：漢族男性（福建人 $90.01 \mathrm{~cm}$, 広東人 $90.68 \mathrm{~cm})$ とアミ族 $(90.62 \mathrm{~cm})$ とは類似した 下肢長を示し，タイヤル族 $(89.06 \mathrm{~cm})$ はやや 小さいが，身長におけるほどの差はみとめられ

Table 1. Stature

\begin{tabular}{l|rccc|cccc}
\hline & \multicolumn{4}{|c|}{$\delta$} & \multicolumn{4}{c}{ o } \\
& $\mathrm{n}$ & $\mathrm{M} \pm \mathrm{m}$ & $\sigma$ & $\mathrm{v}$ & $\mathrm{n}$ & $\mathrm{M} \pm \mathrm{m}$ & $\sigma$ & $\mathrm{v}$ \\
\hline Hoklo Chinese & 221 & $164.57 \pm 0.37$ & 5.46 & 3.32 & 85 & $153.75 \pm 0.46$ & 4.24 & 2.75 \\
Hakka Chinese & 104 & $166.34 \pm 0.54$ & 5.50 & 3.31 & 34 & $155.11 \pm 0.87$ & 5.07 & 3.27 \\
Atayals & 32 & $160.39 \pm 1.02$ & 5.78 & 3.60 & 50 & $152.66 \pm 0.62$ & 4.37 & 2.86 \\
Amis & 30 & $162.44 \pm 0.88$ & 4.84 & 2.98 & 27 & $152.00 \pm 0.63$ & 3.25 & 2.14 \\
\hline
\end{tabular}

Table 2. Leg length

\begin{tabular}{l|rccc|cccc}
\hline & \multicolumn{4}{|c|}{$\delta$} & \multicolumn{4}{c}{ o } \\
\hline & $\mathrm{n}$ & $\mathrm{M} \pm \mathrm{m}$ & $\sigma$ & $\mathrm{v}$ & $\mathrm{n}$ & $\mathrm{M} \pm \mathrm{m}$ & $\sigma$ & $\mathrm{v}$ \\
\hline Hoklo Chinese & 218 & $90.01 \pm 0.27$ & 3.96 & 4.40 & 80 & $84.62 \pm 0.36$ & 3.23 & 3.81 \\
Hakka Chinese & 103 & $90.68 \pm 0.38$ & 3.82 & 4.21 & 33 & $84.68 \pm 0.61$ & 3.51 & 4.15 \\
Atayals & 32 & $98.06 \pm 0.74$ & 4.18 & 4.70 & 50 & $85.82 \pm 0.44$ & 3.13 & 3.65 \\
Amis & 30 & $90.62 \pm 0.65$ & 3.56 & 3.93 & 27 & $84.92 \pm 0.50$ & 2.59 & 3.05 \\
\hline
\end{tabular}

Relative leg length

\begin{tabular}{l|rccc|cccc}
\hline & \multicolumn{4}{|c|}{ o } & \multicolumn{4}{c}{ o } \\
\hline & $\mathrm{n}$ & $\mathrm{M} \pm \mathrm{m}$ & $\sigma$ & $\mathrm{v}$ & $\mathrm{n}$ & $\mathrm{M} \pm \mathrm{m}$ & $\sigma$ & $\mathrm{v}$ \\
\hline Hoklo Chinese & 215 & $54.71 \pm 0.07$ & 1.10 & 2.01 & 80 & $55.05 \pm 0.14$ & 1.22 & 2.22 \\
Hakka Chinese & 102 & $54.53 \pm 0.10$ & 1.04 & 1.90 & 32 & $54.42 \pm 0.28$ & 1.57 & 2.88 \\
Atayals & 32 & $55.51 \pm 0.17$ & 0.99 & 1.78 & 49 & $56.26 \pm 0.14$ & 0.99 & 1.76 \\
A mis & 29 & $55.59 \pm 0.19$ & 1.02 & 1.84 & 27 & $55.86 \pm 0.18$ & 0.91 & 1.63 \\
\hline
\end{tabular}


Fig. 1.

\begin{tabular}{ll|l|l|} 
Hoklo Chinese & 164.57 & $\frac{-\sigma}{1}$ \\
Hakka Chinese & 166.34 & $\frac{M}{1}$ & \\
Atayals & 160.39 & $\frac{1}{1}$ & \\
Amis & 162.44 & $\frac{1}{1}$ &
\end{tabular}

ない。女性ではタイヤル族 $(85.82 \mathrm{~cm})$ が大 きいが，福建人 $(84.62 \mathrm{~cm})$ との差は明確でな W。

平埔族 (男性 $90.32 \mathrm{~cm}$, 女性 $84.39 \mathrm{~cm}$ ) む 漢族やタイヤル，アミ族に近似した值を示し， 身長におけるほどに差が著明でない。

比下肢長：福建人男性（54.71）は広東人 (54.53) と近似している。タイヤル族 $(55.51)$ やアミ族 (55.59) は, 漢族より明らかに大き い。女性でも男性の傾向之同様である。

平埔族男性（55.04）は漢族よりは大きく, タイヤル，アミ族よりは小さいようであるが， 差は明確でない。女性 (55.32) であ同様の乙 とがうかがえる。
Leg length

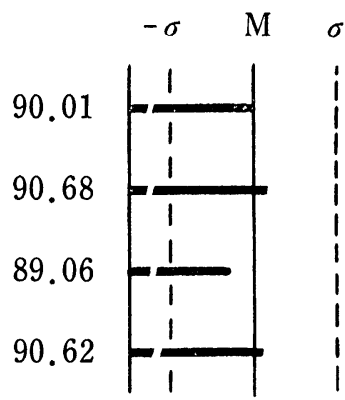

Relative leg length

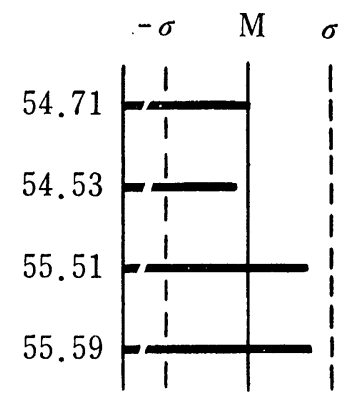

3 ) 軀幹長：比軀幹長 ( Tab. 3)

軀幹長：福建人男性 $(43.03 \mathrm{~cm})$ と広東人男 性 $(43.97 \mathrm{~cm})$ はタイヤル族 $(41.22 \mathrm{~cm})$ およ びアミ族 $(41.04 \mathrm{~cm})$ より大きく，また広東 人は福建人より明らかに大きい。女性でも男性 之同じ傾向がうかがえる。平埔族（男性 43.35 $\mathrm{cm}$, 女性 $39.54 \mathrm{~cm}$ ) は, むしろ漢族に近い。 比軀幹長：福建人男性（26.17） は広東人 (26.41) よりかなり小さく, 漢族男性はタイ ヤル族 (25.70) やアミ族 (25.27) より一般に 大きい。乙とに広東人は高山族より明らかに大 きい。女性での傾向も男性の場合に類似してい る。平埔族（男性 26.4, 女性 25.9) は, 漢族 に近い。

Table 3. Trunk length

\begin{tabular}{l|rccc|cccc}
\hline & \multicolumn{4}{|c|}{$\delta$} & \multicolumn{4}{c}{ o } \\
\hline & $\mathrm{n}$ & $\mathrm{M} \pm \mathrm{m}$ & $\sigma$ & $\mathrm{v}$ & $\mathrm{n}$ & $\mathrm{M} \pm \mathrm{m}$ & $\sigma$ & $\mathrm{v}$ \\
\hline Hoklo Chinese & 215 & $43.03 \pm 0.13$ & 1.95 & 4.53 & 80 & $39.38 \pm 0.22$ & 1.96 & 4.98 \\
Hakka Chinese & 101 & $43.97 \pm 0.20$ & 1.98 & 4.50 & 33 & $40.70 \pm 0.46$ & 2.65 & 6.50 \\
Atayals & 32 & $41.22 \pm 0.34$ & 1.95 & 4.73 & 50 & $38.07 \pm 0.26$ & 1.83 & 4.81 \\
A mis & 30 & $41.04 \pm 0.33$ & 1.83 & 4.46 & 27 & $38.22 \pm 0.28$ & 1.46 & 3.83 \\
\hline
\end{tabular}

Relative trunk length

\begin{tabular}{l|rccc|cccc}
\hline & \multicolumn{4}{|c}{ o } & \multicolumn{4}{c}{ } \\
\hline & \multicolumn{1}{|c}{$\mathrm{n}$} & $\mathrm{M} \pm \mathrm{m}$ & $\sigma$ & $\mathrm{v}$ & $\mathrm{n}$ & $\mathrm{M} \pm \mathrm{m}$ & $\sigma$ & $\mathrm{v}$ \\
\hline Hoklo Chinese & 212 & $26.17 \pm 0.06$ & 0.93 & 3.54 & 80 & $25.62 \pm 0.12$ & 1.08 & 4.20 \\
Hakka Chinese & 100 & $26.41 \pm 0.10$ & 0.99 & 3.75 & 32 & $26.16 \pm 0.24$ & 1.36 & 5.21 \\
Atayals & 32 & $25.70 \pm 0.17$ & 0.98 & 3.81 & 49 & $24.96 \pm 0.16$ & 1.09 & 4.37 \\
Amis & 30 & $25.27 \pm 0.17$ & 0.95 & 3.76 & 27 & $25.15 \pm 0.18$ & 0.94 & 3.72 \\
\hline
\end{tabular}


Table 4. Arm length

\begin{tabular}{l|rccc|cccc}
\hline & \multicolumn{4}{|c}{$\delta$} & \multicolumn{4}{c}{ } \\
& $\mathrm{n}$ & $\mathrm{M} \pm \mathrm{m}$ & $\sigma$ & $\mathrm{v}$ & $\mathrm{n}$ & $\mathrm{M} \pm \mathrm{m}$ & $\sigma$ & $\mathrm{v}$ \\
\hline Hoklo Chinese & 217 & $72.35 \pm 0.21$ & 3.06 & 4.22 & 84 & $67.65 \pm 0.25$ & 2.32 & 3.43 \\
Hakka Chinese & 100 & $72.69 \pm 0.30$ & 2.98 & 4.10 & 34 & $67.89 \pm 0.43$ & 2.51 & 3.70 \\
Atayals & 32 & $72.33 \pm 0.55$ & 3.10 & 4.29 & 51 & $68.72 \pm 0.38$ & 2.69 & 3.91 \\
A mis & 30 & $73.14 \pm 0.49$ & 2.68 & 3.66 & 27 & $66.91 \pm 0.41$ & 2.16 & 3.22 \\
\hline
\end{tabular}

Relative arm length

\begin{tabular}{l|rccc|cccc}
\hline & \multicolumn{5}{|c}{$\delta$} & \multicolumn{4}{c}{ 울 } \\
& $\mathrm{n}$ & $\mathrm{M} \pm \mathrm{m}$ & $\sigma$ & $\mathrm{v}$ & $\mathrm{n}$ & $\mathrm{M} \pm \mathrm{m}$ & $\sigma$ & $\mathrm{v}$ \\
\hline Hoklo Chinese & 215 & $44.00 \pm 0.08$ & 1.11 & 2.53 & 83 & $44.01 \pm 0.12$ & 1.11 & 2.51 \\
Hakka Chinese & 99 & $43.76 \pm 0.11$ & 1.09 & 2.50 & 33 & 43.68 上0.17 & 1.00 & 2.30 \\
Atayals & 31 & $45.23 \pm 0.16$ & 0.90 & 1.99 & 50 & $45.06 \pm 0.16$ & 1.12 & 2.48 \\
Amis & 30 & $45.03 \pm 0.20$ & 1.08 & 2.41 & 27 & $44.01 \pm 0.17$ & 0.89 & 2.01 \\
\hline
\end{tabular}

Fig. 2.

Hoklo Chinese

Hakka Chinese

Atayals

Amis

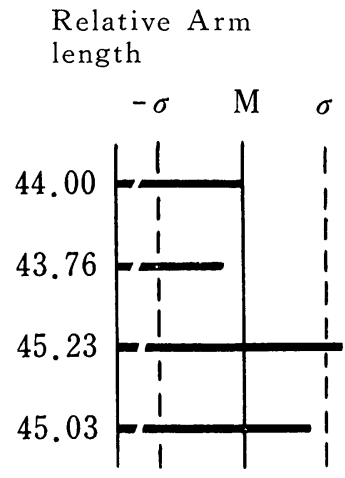

4）上肢長：比上肢長 (Tab. 4, Fig. 2)

上肢長：男女性ともタイヤル族（男性 72.33 $\mathrm{cm}$, 女性 $68.72 \mathrm{~cm}$ ) とアミ族（男性 73.14 $\mathrm{cm}$, 女性 $66.91 \mathrm{~cm}$ ) との差は大きく，女性で の差は確かである。平埔族（男性 $73.70 \mathrm{~cm}$, 女性 $68.66 \mathrm{~cm}$ ) の值はやや大きい。しかし, 漢族を含めて種族間, 男女間の差に一定の傾向 は見出せない。

比上肢長：男性では漢族は高山族より一般に 小さく，差も明瞭であるが，女性ではタイヤル 族 (45.06) が他の種族より大きい。平埔族（男 性 45.01, 女性 44.89）の值はやや大きい。

5 ) 屃峰巾, 比疦峰巾（Tab. 5, Fig. 2)
Relative

Biacrom. br.

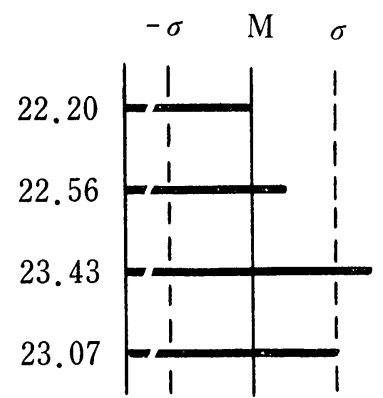

Pelvic br.

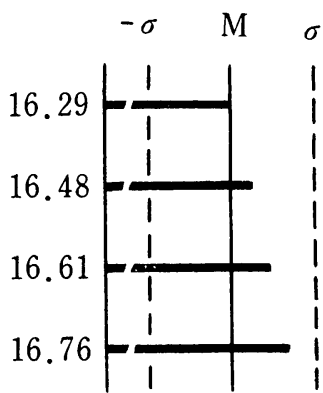

屃峰巾：福建人男性 $(36.52 \mathrm{~cm})$ は広東人 $(37.46 \mathrm{~cm})$ より小さい。タイヤル族 $(37.47$ $\mathrm{cm})$, アミ族 $(37.49 \mathrm{~cm})$ は広東人に近い。女 性での傾向は男性におけるもの之異なり, 種族 間の差は明膫でない。平埔族（男性 $38.08 \mathrm{~cm}$, 女性 $34.70 \mathrm{~cm}$ ) は大きい值を示す。

比肩峰巾：福建人男性（22.20）は広東人 （22.56）より明らかに小さく，両集団の差を 示している。てれら漢族はタイヤル族 (23.43), アミ族（23.07）よりかなり小さい。女性での 種族差は男性におけるほど明確でない。平埔族 の值はかなり大きい。

6）骨盤巾，比骨盤币（Tab. 6, Fig. 2) 
Table 5. Biacromial breadth

\begin{tabular}{l|rccc|cccc} 
& \multicolumn{4}{|c}{ o } & \multicolumn{4}{c}{ o } \\
\hline & $\mathrm{n}$ & $\mathrm{M} \pm \mathrm{m}$ & $\sigma$ & $\mathrm{v}$ & $\mathrm{n}$ & $\mathrm{M} \pm \mathrm{m}$ & $\sigma$ & $\mathrm{v}$ \\
\hline Hoklo Chinese & 221 & $36.52 \pm 0.10$ & 1.53 & 4.19 & 85 & $33.96 \pm 0.13$ & 1.16 & 3.43 \\
Hakka Chinese & 104 & $37.46 \pm 0.17$ & 1.74 & 4.65 & 33 & $34.47 \pm 0.20$ & 1.15 & 3.34 \\
Atayals & 31 & $37.47 \pm 0.24$ & 1.31 & 3.51 & 50 & $33.73 \pm 0.19$ & 1.31 & 3.88 \\
Amis & 30 & $37.49 \pm 0.36$ & 1.97 & 5.24 & 28 & $34.41 \pm 0.26$ & 1.36 & 3.94 \\
\hline
\end{tabular}

Relative biacromial breadth

\begin{tabular}{l|rccc|cccc}
\hline & \multicolumn{4}{|c|}{ o } & \multicolumn{4}{c}{ 市 } \\
\hline & $\mathrm{n}$ & $\mathrm{M} \pm \mathrm{m}$ & $\sigma$ & $\mathrm{v}$ & $\mathrm{n}$ & $\mathrm{M} \pm \mathrm{m}$ & $\sigma$ & $\mathrm{v}$ \\
\hline Hoklo Chinese & 216 & $22.20 \pm 0.06$ & 0.85 & 3.82 & 83 & $22.09 \pm 0.07$ & 0.67 & 3.04 \\
Hakka Chinese & 103 & $22.56 \pm 0.08$ & 0.86 & 3.82 & 32 & $22.17 \pm 0.16$ & 0.90 & 4.08 \\
Atayals & 31 & $23.43 \pm 0.15$ & 0.82 & 3.48 & 49 & $22.11 \pm 0.11$ & 0.79 & 3.58 \\
Amis & 30 & $23.07 \pm 0.16$ & 0.88 & 3.80 & 27 & $22.59 \pm 0.15$ & 0.76 & 3.36 \\
\hline
\end{tabular}

骨盤巾：福建人男性（26.81 cm）は広東人 タイヤル族（16.61）やアミ族（16.76）よりは $(27.40 \mathrm{~cm})$ より明らかに小さい。タイヤル族

$(26.63 \mathrm{~cm})$, アミ族 $(27.22 \mathrm{~cm})$ ならびに平 埔族 $(27.16 \mathrm{~cm})$ との差は明確でない。

女性での種族差（平埔族 $27.55 \mathrm{~cm}$ ) は明ら かでない。

比骨盤巾：福建人男性（16. 29） は広東人 巾では高山族が，比軀幹長では漢族が優れてい （16.48）よりやや小さいが，差は明瞭でなく，るようである。高山族での比例值の大きい場合
るかに小さい。漢族間での差は骨盤巾に，高山 族との差は身長に起因しているようである。 体部のまとめ

漢族は高山族にくらべて，身長，衄幹長がま さり，比下肢長，比上肢長，比肩峰巾，比骨盤

Table 6. Pelvic breadth

\begin{tabular}{l|rccc|cccc}
\hline & \multicolumn{4}{|c|}{ o } & \multicolumn{4}{|c}{ o } \\
& $\mathrm{n}$ & $\mathrm{M} \pm \mathrm{m}$ & $\sigma$ & $\mathrm{v}$ & $\mathrm{n}$ & $\mathrm{M} \pm \mathrm{m}$ & $\sigma$ & $\mathrm{v}$ \\
\hline Hoklo Cninese & 218 & $26.81 \pm 0.09$ & 1.31 & 4.88 & 82 & $27.26 \pm 0.14$ & 1.31 & 4.81 \\
Hakka Chinese & 103 & $27.40 \pm 0.13$ & 1.33 & 4.86 & 34 & $27.65 \pm 0.24$ & 1.39 & 5.01 \\
Atayals & 32 & $26.63 \pm 0.20$ & 1.16 & 4.34 & 51 & $27.08 \pm 0.18$ & 1.30 & 4.81 \\
Amis & 30 & $27.22 \pm 0.27$ & 1.49 & 5.48 & 28 & $27.48 \pm 0.23$ & 1.24 & 4.52 \\
\hline
\end{tabular}

Relative Pelvic breadth

\begin{tabular}{l|rccc|cccc}
\hline & \multicolumn{4}{|c|}{$\delta$} & \multicolumn{4}{c}{ o } \\
& $\mathrm{n}$ & $\mathrm{M} \pm \mathrm{m}$ & $\sigma$ & $\mathrm{v}$ & $\mathrm{n}$ & $\mathrm{M} \pm \mathrm{m}$ & $\sigma$ & $\mathrm{v}$ \\
\hline Hoklo Chinese & 215 & $16.29 \pm 0.05$ & 0.68 & 4.15 & 81 & $17.74 \pm 0.09$ & 0.81 & 4.59 \\
Hakka Chinese & 103 & $16.48 \pm 0.07$ & 0.69 & 4.18 & 33 & $17.79 \pm 0.16$ & 0.90 & 5.06 \\
Atayals & 32 & $16.61 \pm 0.11$ & 0.61 & 3.70 & 50 & $17.77 \pm 0.11$ & 0.75 & 4.24 \\
Amis & 30 & $16.76 \pm 0.16$ & 0.88 & 5.24 & 27 & $18.00 \pm 0.12$ & 0.61 & 3.41 \\
\hline
\end{tabular}


はその身長に影響されているようであり，稫幹 長, 比稫幹長に漢族の特性がうかがえそうであ る。

広東人は福建人にくらべて, 身長, 軀幹長, 局峰巾，骨盤巾がまさっている。比例值では広 東人の比軀幹長, 比上肢長がわずかに大きく， 比留峰巾，比骨盤币では福建人よりかなり大 きい。一般に広東人の体部が福建人のそれより 大きいようである。

アミ族の身長，下肢長，骨盤巾がややタイヤ ル族より優る。比例值で, タイヤル族の比稫幹 長, 比肩峰巾がアミ族よりやや大きいのは，身 長が関係し，アミ族の比骨盤巾の大きさは絶対
值によるあのであろう。

\section{II）頭部について}

\section{7 ) 頭長 (Tab. 7, Fig. 3)}

漢族男性では福建人 $(185.31 \mathrm{~mm})$ は広東人 (187.16 mm) より，また高山族のタイヤル族 $(185.47 \mathrm{~mm})$ はアミ族 $(188.62 \mathrm{~mm})$ よりか なり小さい。しかし，漢族と高山族との差はみ とめられない。女性であ男性における傾向とほ ぼ等しい。

平埔族 (男性 $185.46 \mathrm{~mm}$, 女性 $178.10 \mathrm{~mm}$ ) は小さい方である。

8 ) 頭巾 (Tab. 8, Fig. 3)

漢族男性では福建人（153.41 mm）は広東人

Table 7. Cephalic length

\begin{tabular}{l|rccc|cccc}
\hline & \multicolumn{4}{|c|}{$\delta$} & \multicolumn{4}{c}{ o } \\
\hline & $\mathrm{n}$ & $\mathrm{M} \pm \mathrm{m}$ & $\sigma$ & $\mathrm{v}$ & $\mathrm{n}$ & $\mathrm{M} \pm \mathrm{m}$ & $\sigma$ & $\mathrm{v}$ \\
\hline Hoklo Chinese & 223 & $185.31 \pm 0.49$ & 7.35 & 3.97 & 84 & $179.21 \pm 0.65$ & 5.96 & 3.33 \\
Hakka Chinese & 104 & $187.16 \pm 0.64$ & 6.48 & 3.46 & 35 & $180.37 \pm 1.01$ & 5.96 & 3.30 \\
Atayals & 32 & $185.47 \pm 0.92$ & 5.18 & 2.79 & 51 & $180.43 \pm 0.79$ & 5.66 & 3.14 \\
Amis & 29 & $188.62 \pm 1.11$ & 5.99 & 3.17 & 28 & $182.43 \pm 1.00$ & 5.30 & 2.90 \\
\hline
\end{tabular}

Table 8. Cephalic breadth

\begin{tabular}{l|rccc|cccc}
\hline & \multicolumn{4}{|c|}{$\delta$} & \multicolumn{4}{c}{ 울 } \\
& \multicolumn{1}{|c|}{$\mathrm{n}$} & $\mathrm{M} \pm \mathrm{m}$ & $\sigma$ & $\mathrm{v}$ & $\mathrm{n}$ & $\mathrm{M} \pm \mathrm{m}$ & $\sigma$ & $\mathrm{v}$ \\
\hline Hoklo Chinese & 222 & $153.41 \pm 0.37$ & 5.46 & 3.56 & 84 & $146.82 \pm 0.62$ & 5.67 & 3.86 \\
Hakka Chinese & 103 & $155.01 \pm 0.56$ & 5.67 & 3.66 & 35 & $147.06 \pm 0.78$ & 4.59 & 3.12 \\
Atayals & 32 & $146.88 \pm 0.86$ & 4.88 & 3.33 & 51 & $141.41 \pm 0.61$ & 4.33 & 3.06 \\
Amis & 30 & $147.37 \pm 1.08$ & 5.90 & 4.01 & 28 & $143.36 \pm 0.73$ & 3.86 & 2.69 \\
\hline
\end{tabular}

Fig. 3.

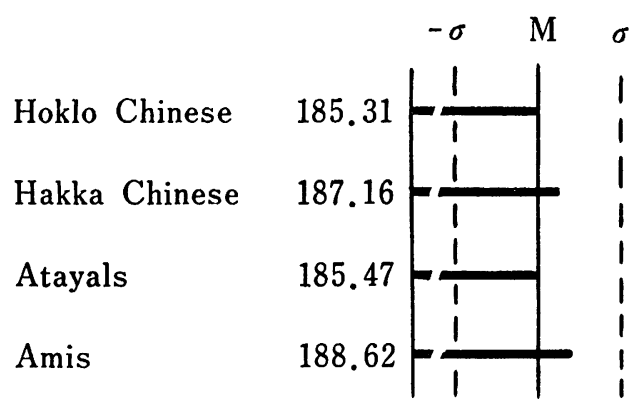

Cephalic breadth

Cephalic index

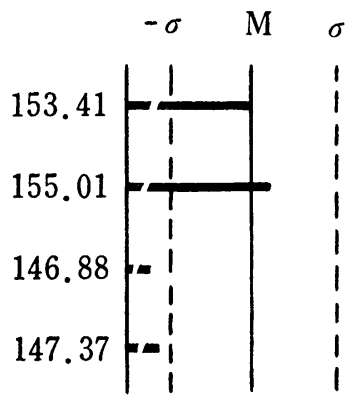

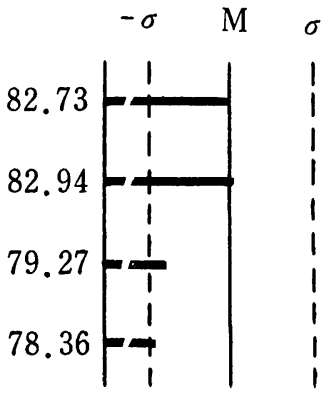


（155.01 mm）よりかなり小さく,タイヤル, ア ミ両族の間には差はみとめられない。熯族は高 山族より明らかに大きい。女性においてす男性 での傾向と同様であるが，タイヤル族（141.41 $\mathrm{mm}$ ) はアミ族 $(143.36 \mathrm{~mm})$ よりかなり小さ い。

平埔族男性 (151. $38 \mathrm{~mm}$ ) は漢族に近く, 女 性 $(144.51 \mathrm{~mm})$ は漢族と高山族との中間の值 を示す。

9 ) 頭長巾指数（Tab. 9, Fig. 3)

福建人男性（82.73）と広東人（82.94）は近 似し，短頭に属する。タイヤル族 (79.27) は アミ族（78.36）よりわずかに大きいが，差は
不明である。高山族は中頭の上限に位し，漢族 との差は明らかである。平埔族は両種族の中間 の值（80.03）を示す。

女性も男性の状態に近い傾向を示す。

10）頭耳高（Tab. 10, Fig. 4)

福建人男性（130.40 mm） と広東人（131.22 $\mathrm{mm})$ とは近似し, タイヤル族 $(125.34 \mathrm{~mm})$ とアミ族 $(126.83 \mathrm{~mm})$ の差もみとめがたい。 漢族は高山族よりかなり大きく，その差むほぼ みとめうる。平埔族 $(122.28 \mathrm{~mm})$ は極めて小 さい。

女性においては男性と類似した傾向がある。 11）頭長高指数（Tab. 11, Fig. 4）

Table 9. Cephalic length breadth index

\begin{tabular}{l|rccc|cccc}
\hline & \multicolumn{4}{|c|}{ o } & \multicolumn{4}{c}{ o } \\
\hline & $\mathrm{n}$ & $\mathrm{M} \pm \mathrm{m}$ & $\sigma$ & $\mathrm{v}$ & $\mathrm{n}$ & $\mathrm{M} \pm \mathrm{m}$ & $\sigma$ & $\mathrm{v}$ \\
\hline Hoklo Chinsee & 219 & $82.73 \pm 0.31$ & 4.54 & 5.48 & 80 & $81.66 \pm 0.46$ & 4.11 & 5.04 \\
Hakka Chinese & 103 & $82.94 \pm 0.45$ & 4.60 & 5.55 & 35 & $81.60 \pm 0.58$ & 3.44 & 4.22 \\
Atayals & 32 & $79.27 \pm 0.68$ & 3.86 & 4.87 & 51 & $78.44 \pm 0.47$ & 3.33 & 4.24 \\
Amis & 29 & $78.36 \pm 0.74$ & 3.97 & 5.06 & 28 & $78.64 \pm 0.55$ & 2.91 & 3.70 \\
\hline
\end{tabular}

Table 10. Cephalic height

\begin{tabular}{l|rccc|cccc}
\hline & \multicolumn{4}{|c|}{$\delta$} & \multicolumn{4}{c}{ o } \\
\hline & $\mathrm{n}$ & $\mathrm{M} \pm \mathrm{m}$ & $\sigma$ & $\mathrm{v}$ & $\mathrm{n}$ & $\mathrm{M} \pm \mathrm{m}$ & $\sigma$ & $\mathrm{v}$ \\
\hline Hoklo Chinese & 217 & $130.40 \pm 0.41$ & 6.02 & 4.62 & 84 & $124.91 \pm 0.59$ & 5.42 & 4.34 \\
Hakka Chinese & 102 & $131.22 \pm 0.72$ & 7.29 & 5.56 & 34 & $124.91 \pm 0.94$ & 5.47 & 4.38 \\
Atayals & 32 & $125.34 \pm 0.87$ & 4.94 & 3.94 & 50 & $121.36 \pm 0.77$ & 5.42 & 4.47 \\
Amis & 29 & $126.83 \pm 1.13$ & 6.08 & 4.80 & 27 & $122.89 \pm 1.06$ & 5.49 & 4.46 \\
\hline
\end{tabular}

Fig. 4.

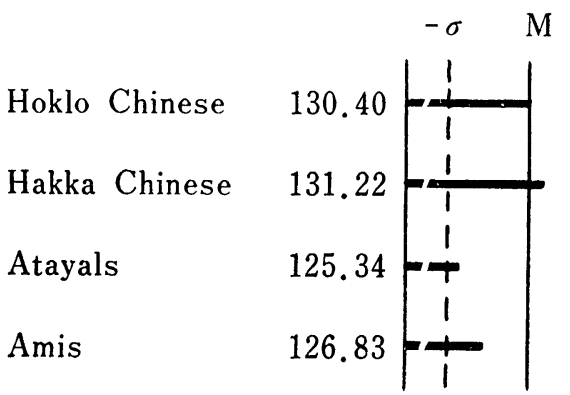

Leng.-height index

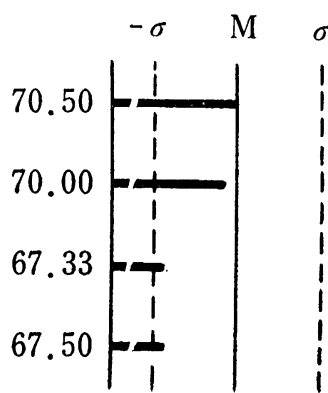

Brea.-height index

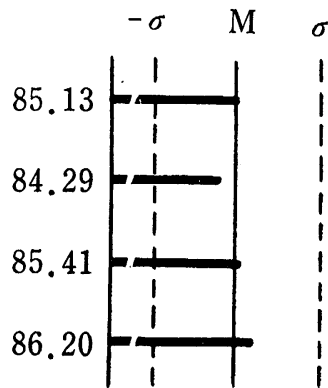


Table 11. Cephalic length height index

\begin{tabular}{l|rccc|cccc}
\hline & \multicolumn{4}{|c|}{ o } & \multicolumn{4}{c}{ o } \\
\hline & $\mathrm{n}$ & $\mathrm{M} \pm \mathrm{m}$ & $\sigma$ & $\mathrm{v}$ & $\mathrm{n}$ & $\mathrm{M} \pm \mathrm{m}$ & $\sigma$ & $\mathrm{v}$ \\
\hline Hoklo Chinese & 215 & $70.50 \pm 0.24$ & 3.59 & 5.09 & 81 & $69.55 \pm 0.37$ & 3.34 & 4.80 \\
Hakka Chinese & 101 & $70.00 \pm 0.36$ & 3.65 & 5.22 & 34 & $69.40 \pm 0.68$ & 3.96 & 5.71 \\
Atayals & 31 & $67.33 \pm 0.51$ & 2.85 & 4.23 & 49 & $67.12 \pm 0.46$ & 3.24 & 4.82 \\
Amis & 28 & $67.50 \pm 0.61$ & 3.20 & 4.75 & 27 & $67.52 \pm 0.57$ & 2.96 & 4.38
\end{tabular}

Cephalic breadth height index

\begin{tabular}{l|rccc|cccc}
\hline & \multicolumn{4}{|c|}{$\delta$} & \multicolumn{4}{c}{ o } \\
& $\mathrm{n}$ & $\mathrm{M} \pm \mathrm{m}$ & $\sigma$ & $\mathrm{v}$ & $\mathrm{n}$ & $\mathrm{M} \pm \mathrm{m}$ & $\sigma$ & $\mathrm{v}$ \\
\hline Hoklo Chinese & 213 & $85.13 \pm 0.29$ & 4.16 & 4.89 & 82 & $85.13 \pm 0.44$ & 3.94 & 4.63 \\
Hakka Chinese & 100 & $84.29 \pm 0.41$ & 4.08 & 4.84 & 33 & $85.49 \pm 0.66$ & 3.80 & 4.45 \\
Atayals & 32 & $85.41 \pm 0.71$ & 4.02 & 4.71 & 50 & $85.84 \pm 0.61$ & 4.31 & 5.02 \\
Amis & 29 & $86.20 \pm 0.75$ & 4.05 & 4.70 & 27 & $85.90 \pm 0.84$ & 4.35 & 5.06 \\
\hline
\end{tabular}

福建人男性 (70.50) は広東人 (70.00) より わずかに大きいようであるが，不明確であり， タイヤル族 (67.33) とアミ族 (67.50) とは近 似している。漢族は高山族より大きい。平埔族

(64.83) はいちじるしく小さい。

女性でも, 漢族間, 高山族間の值は近似し， 漢族は高山族より大きい。

12）頭巾高指数（Tab. 11, Fig. 4)

福建人男性 (85.13) は広東人 (84.29) より わずかに大きく，タイヤル族 $(85.41)$ とアミ 族 (86.20) との差はみとめがたい。漢族と高 山族との差は頭長高指数におけるほどに明瞭で ない。平埔族は小さい。

女性では差がはるかに不明瞭となる。

頭部のまとめ

頭長では漢族と高山族との差は不明である
が，頭巾では漢族がまさっている。漢族では， 福建人はやや小さい。

頭長巾指数では漢族が高山族より明らかに大 きい。平埔族は中間の值を示す。

頭耳高も漢族が高山族より大きい。その指数 としては漢族の頭長高指数が大きい。頭巾高指 数での種族差は不明瞭である。

頭長, 頭巾, 頭耳高で広東人が福建人よりも 頭耳高でアミ族がタイヤル族より大きいようで あり，アミ族の頭長はタイヤル族より大きいよ うである。

\section{III）顔部について}

13）煩骨弓巾（Tab. 12, Fig. 5)

福建人男性 $(144.09 \mathrm{~mm})$ は広東人（146.78 $\mathrm{mm}$ ) より明らかに小さく，高山族間の差はみ とめがたい。漢族は高山族よりかなり大きい。

Table 12. Bizygomatic breadth

\begin{tabular}{l|rccc|cccc}
\hline & \multicolumn{4}{|c|}{$\delta$} & \multicolumn{4}{c}{ o } \\
\hline & $\mathbf{n}$ & $\mathbf{M} \pm \mathbf{m}$ & $\sigma$ & $\mathbf{v}$ & $\mathrm{n}$ & $\mathrm{M} \pm \mathrm{m}$ & $\sigma$ & $\mathrm{v}$ \\
\hline Hoklo Chinese & 221 & $144.09 \pm 0.29$ & 4.34 & 3.01 & 86 & $138.05 \pm 0.50$ & 4.61 & 3.34 \\
Hakka Chinese & 104 & $146.78 \pm 0.51$ & 5.15 & 3.51 & 34 & $140.59 \pm 0.76$ & 4.43 & 3.15 \\
Atayals & 32 & $141.50 \pm 0.85$ & 4.80 & 3.39 & 51 & $135.02 \pm 0.50$ & 3.58 & 2.65 \\
Amis & 30 & $142.73 \pm 1.01$ & 5.51 & 3.86 & 28 & $138.18 \pm 0.61$ & 3.23 & 2.34 \\
\hline
\end{tabular}


Fig. 5.

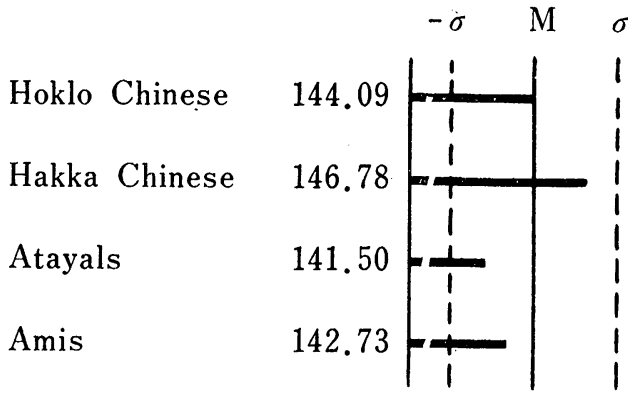

Physiog. facial h.

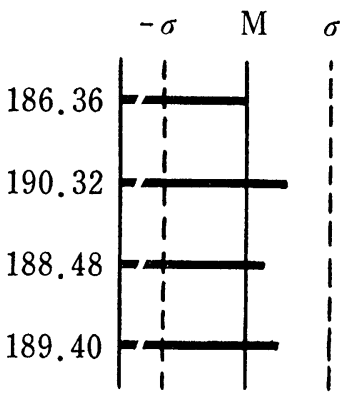

Physiog. facial i.

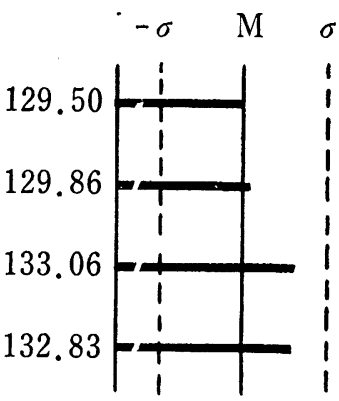

Table 13. Tr. cephalo-facial index

\begin{tabular}{l|rccc|cccc}
\hline & \multicolumn{4}{|c|}{$\delta$} & \multicolumn{4}{c}{ o } \\
\hline & $\mathrm{n}$ & $\mathrm{M} \pm \mathrm{m}$ & $\sigma$ & $\mathrm{v}$ & $\mathrm{n}$ & $\mathrm{M} \pm \mathrm{m}$ & $\sigma$ & $\mathrm{v}$ \\
\hline Hoklo Chinese & 219 & $93.94 \pm 0.20$ & 2.97 & 3.16 & 83 & $94.17 \pm 0.29$ & 2.61 & 2.77 \\
Hakka Chinese & 102 & $94.71 \pm 0.26$ & 2.58 & 2.73 & 34 & $95.50 \pm 0.46$ & 2.70 & 2.83 \\
Atayals & 32 & $96.37 \pm 0.43$ & 2.44 & 2.53 & 50 & $95.67 \pm 0.35$ & 2.49 & 2.60 \\
Amis & 29 & $96.56 \pm 0.41$ & 2.23 & 2.31 & 28 & $96.42 \pm 0.38$ & 2.01 & 2.08 \\
\hline
\end{tabular}

平埔族（144.57 mm）は漠族に近い。

女性での傾向は男性におけるすのと類似して いるが男性ほよ゙に著明でない。

14）頭顔指数（Tab. 13）

福建人男性（93.94）牥東人（94.71）より かなり小さく，高山族での差はみとめられな
い。漢族は高山族より小さい。漠族は高山族に くらべて頭巾, 頬骨弓巾ともに大きいが, 頭巾 における差がより著明である。平埔族（95.45） は漢族と高山族との中間の值を示す。

女性における漢族と高山族との差は男性ほど 顕著でない。

Table1 14. Bigonial breadth

\begin{tabular}{l|rrcc|cccc}
\hline & \multicolumn{4}{|c|}{ o } & \multicolumn{4}{c}{ o } \\
& \multicolumn{1}{|c}{$\mathrm{n}$} & \multicolumn{1}{c|}{$\mathrm{M} \pm \mathrm{m}$} & $\sigma$ & $\mathrm{v}$ & $\mathrm{n}$ & $\mathrm{M} \pm \mathrm{m}$ & $\sigma$ & $\mathrm{v}$ \\
\hline Hoklo Chinese & 222 & $98.79 \pm 0.30$ & 4.43 & 4.48 & 86 & $92.29 \pm 0.38$ & 3.50 & 3.80 \\
Hakka Chinese & 104 & $100.56 \pm 0.44$ & 4.45 & 4.43 & 34 & $93.21 \pm 0.70$ & 4.07 & 4.37 \\
Atayals & 32 & $98.34 \pm 0.69$ & 3.87 & 3.94 & 51 & $92.10 \pm 0.43$ & 3.09 & 3.35 \\
A mis & 30 & $98.77 \pm 0.85$ & 4.66 & 4.72 & 28 & $93.50 \pm 0.75$ & 3.97 & 4.24
\end{tabular}

Zygomandibular index

\begin{tabular}{l|rccc|cccc}
\hline & \multicolumn{4}{|c|}{ o } & \multicolumn{4}{c}{ o } \\
\hline & $\mathrm{n}$ & $\mathrm{M} \pm \mathrm{m}$ & $\sigma$ & $\mathrm{v}$ & $\mathrm{n}$ & $\mathrm{M} \pm \mathrm{m}$ & $\sigma$ & $\mathrm{v}$ \\
\hline Hoklo Chinese & 217 & $68.55 \pm 0.18$ & 2.69 & 3.92 & 86 & $66.89 \pm 0.27$ & 2.47 & 3.70 \\
Hakka Chinese & 102 & $68.55 \pm 0.27$ & 2.70 & 3.94 & 34 & $66.31 \pm 0.40$ & 2.33 & 3.51 \\
Atayals & 32 & $69.53 \pm 0.43$ & 2.43 & 3.50 & 50 & $68.10 \pm 0.34$ & 2.43 & 3.57 \\
Amis & 30 & $69.22 \pm 0.48$ & 2.64 & 3.81 & 28 & $67.70 \pm 0.60$ & 3.16 & 4.67 \\
\hline
\end{tabular}


Table 15. Physiognomic facial height

\begin{tabular}{l|rccc|cccc}
\hline & \multicolumn{4}{|c|}{$\delta$} & \multicolumn{4}{c}{ o } \\
\hline & $\mathrm{n}$ & $\mathrm{M} \pm \mathrm{m}$ & $\sigma$ & $\mathrm{v}$ & $\mathrm{n}$ & $\mathrm{M} \pm \mathrm{m}$ & $\sigma$ & $\mathrm{v}$ \\
\hline Hoklo Chinese & 220 & $186.36 \pm 0.54$ & 7.97 & 4.28 & 83 & $178.75 \pm 0.71$ & 6.42 & 3.59 \\
Hakka Chinese & 99 & $190.32 \pm 0.85$ & 8.49 & 4.46 & 35 & $180.06 \pm 1.14$ & 6.74 & 3.74 \\
Atayals & 31 & $188.48 \pm 1.56$ & 8.69 & 4.61 & 49 & $178.47 \pm 1.19$ & 8.32 & 4.66 \\
Amis & 30 & $189.40 \pm 1.54$ & 8.43 & 4.45 & 28 & $182.00 \pm 1.25$ & 6.62 & 3.64 \\
\hline
\end{tabular}

Physiognomic facial index

\begin{tabular}{l|rccc|cccc}
\hline & \multicolumn{5}{|c|}{$\delta$} & \multicolumn{4}{c}{ o } \\
\hline & $\mathrm{n}$ & $\mathrm{M} \pm \mathrm{m}$ & $\sigma$ & $\mathrm{v}$ & $\mathrm{n}$ & $\mathrm{M} \pm \mathrm{m}$ & $\sigma$ & $\mathrm{v}$ \\
\hline Hoklo Chinese & 216 & $129.50 \pm 0.38$ & 5.56 & 4.30 & 83 & $129.53 \pm 0.64$ & 5.81 & 4.49 \\
Hakka Chinese & 98 & $129.86 \pm 0.63$ & 6.21 & 4.78 & 34 & $127.86 \pm 1.03$ & 6.00 & 4.69 \\
Atayals & 31 & $133.06 \pm 1.03$ & 5.71 & 4.29 & 49 & $132.24 \pm 1.01$ & 7.10 & 5.37 \\
Amis & 30 & $132.83 \pm 1.22$ & 6.66 & 5.01 & 28 & $131.73 \pm 0.82$ & 4.33 & 3.29 \\
\hline
\end{tabular}

15）下顎角巾, 下顎角指数（Tab. 14）

下顎角巾：福建人男性 $(98.79 \mathrm{~mm}$ ) は広東 人 $(100.56 \mathrm{~mm})$ より小さく，またタイヤル族 $(98.34 \mathrm{~mm})$ やアミ族 $(98.77 \mathrm{~mm})$ との差は みとめがたい。平埔族 $(113.05 \mathrm{~mm})$ はかなり 大きい。

女性での差は小さい。

下顎角指数：漢族男性間の差はみとめられ ず,高山族よりわずかに小さい。平埔族 (78.38) は大きい。

女性でも高山族はやや大きい。

16）容貌顔面高, 容貌顔面指数（Tab. 15）

(Fig. 5)

容貌顔面高：福建人男性 $(186.36 \mathrm{~mm})$ は広 東人 $(190.32 \mathrm{~mm})$ より明らかに小さく，タイ ヤル族 (188. $48 \mathrm{~mm})$ は漢族の中間に, アミ族 $(189.40 \mathrm{~mm})$ は広東人に近いが漢族との間に 明確な関係は指摘されない。平埔族（185.86 $\mathrm{mm}$ )はかなり小さく，福建人に近い。

女性においても漢族では広東人が，高山族で はアミ族が大きいようである。

容貌顔面指数：福建人男性（129.50）は広東 人 (129.86) と，またタイヤル族 (133.06) は
アミ族（132.83）と相互に近似している。漢族 は高山族よりかなり小さい。平埔族（128.65）

は高山族よりかなり小さい。

女性では漢族と高山族との関係は男性に似る が，平埔族（132.84）はかなり大きい。また平 埔族の性差は大きい。

17）眼内角巾, 口巾（Tab. 16）

眼内角巾: 福建人男性 $(34.38 \mathrm{~mm})$ は広東 人 $(34.30 \mathrm{~mm})$ と近似し，漢族はタイヤル族 $(33.34 \mathrm{~mm})$ ，アミ族 $(33.10 \mathrm{~mm})$ よりかな り大きい。平埔族は漢族と高山族との中間に位 する。

女性でも 漢族は高山族より大きいようであ る。

口币：福建人男性 $(50.81 \mathrm{~mm})$ は広東人 $(51.47 \mathrm{~mm})$ より, タイヤル族 $(50.97 \mathrm{~mm})$ はアミ族 $(53.67 \mathrm{~mm})$ よりかなり小さい。種 族差はみとめがたいが，アミ族男性はかなり 大きい。

女性においても種族差はみとめがたい。

18）鼻高，鼻巾，鼻高巾指数（Tab. 17, Fig. 6)

鼻高：福建人男性 $(62,46 \mathrm{~mm})$ は広東人 
Table 16. Inter-canthic breadth

\begin{tabular}{l|rccc|cccc}
\hline & \multicolumn{4}{|c|}{ o } & \multicolumn{4}{c}{ o } \\
\hline & $\mathrm{n}$ & $\mathrm{M} \pm \mathrm{m}$ & $\sigma$ & $\mathrm{v}$ & $\mathrm{n}$ & $\mathrm{M} \pm \mathrm{m}$ & $\sigma$ & $\mathrm{v}$ \\
\hline Hoklo Chinese & 221 & $34.38 \pm 0.15$ & 2.19 & 6.38 & 85 & $33.94 \pm 0.24$ & 2.25 & 6.62 \\
Hakka Chinese & 103 & $34.30 \pm 0.26$ & 2.59 & 7.56 & 35 & $33.40 \pm 0.35$ & 2.05 & 6.13 \\
Atayals & 32 & $33.34 \pm 0.35$ & 1.98 & 5.93 & 51 & $32.49 \pm 0.28$ & 1.98 & 6.11 \\
Amis & 30 & $33.10 \pm 0.42$ & 2.28 & 6.89 & 28 & $32.79 \pm 0.41$ & 2.15 & 6.56 \\
\hline
\end{tabular}

Mouth breadth

\begin{tabular}{l|rccc|cccc}
\hline & \multicolumn{9}{|c|}{$\delta$} & \multicolumn{4}{c}{ o } \\
\hline & $\mathrm{n}$ & $\mathrm{M} \pm \mathrm{m}$ & $\sigma$ & $\mathrm{v}$ & $\mathrm{n}$ & $\mathrm{M} \pm \mathrm{m}$ & $\sigma$ & $\mathrm{v}$ \\
\hline Hoklo Chinese & 215 & $50.81 \pm 0.70$ & 2.96 & 5.83 & 83 & $48.74 \pm 0.28$ & 2.59 & 5.32 \\
Hakka Chinese & 99 & $51.47 \pm 0.28$ & 2.75 & 5.33 & 35 & $50.57 \pm 0.48$ & 2.83 & 5.60 \\
Atayals & 31 & $50.97 \pm 0.42$ & 2.36 & 4.63 & 48 & $48.65 \pm 0.31$ & 2.13 & 4.38 \\
Amis & 30 & $53.67 \pm 0.69$ & 3.79 & $\overline{7.06}$ & 27 & $50.15 \pm 0.55$ & 2.88 & 5.74 \\
\hline
\end{tabular}

Table 17. Nasal height

\begin{tabular}{l|rccc|cccc}
\hline & \multicolumn{4}{|c|}{$\delta$} & \multicolumn{4}{c}{ o } \\
\hline & $\mathrm{n}$ & $\mathrm{M} \pm \mathrm{m}$ & $\sigma$ & $\mathrm{v}$ & $\mathrm{n}$ & $\mathrm{M} \pm \mathrm{m}$ & $\sigma$ & $\mathrm{v}$ \\
\hline Hoklo Chinese & 223 & $62.46 \pm 0.24$ & 3.51 & 5.62 & 84 & $58.58 \pm 0.29$ & 2.64 & 4.51 \\
Hakka Chinese & 104 & $61.61 \pm 0.33$ & 3.36 & 5.45 & 33 & $58.21 \pm 0.45$ & 2.57 & 4.42 \\
Atayals & 32 & $60.34 \pm 0.59$ & 3.32 & 5.50 & 51 & $56.28 \pm 0.34$ & 2.46 & 4.37 \\
Amis & 30 & $60.33 \pm 0.49$ & 2.70 & 4.47 & 28 & $57.46 \pm 0.58$ & 3.06 & 5.33 \\
\hline
\end{tabular}

Nasal breadth

\begin{tabular}{l|rccc|cccc}
\hline & \multicolumn{4}{|c|}{ o } & \multicolumn{4}{c}{ o } \\
\hline & $\mathrm{n}$ & $\mathrm{M} \pm \mathrm{m}$ & $\sigma$ & $\mathrm{v}$ & $\mathrm{n}$ & $\mathrm{M} \pm \mathrm{m}$ & $\sigma$ & $\mathrm{v}$ \\
\hline Hoklo Chinese & 221 & $37.99 \pm 0.16$ & 2.38 & 6.25 & 85 & $35.81 \pm 0.22$ & 2.07 & 5.77 \\
Hakka Chinese & 103 & $38.67 \pm 0.28$ & 2.82 & 7.30 & 35 & $37.03 \pm 0.51$ & 2.99 & 8.06 \\
Atayals & 32 & $37.00 \pm 0.39$ & 2.20 & 5.95 & 51 & $34.08 \pm 0.29$ & 2.08 & 6.09 \\
Amis & 29 & $39.38 \pm 0.41$ & 2.21 & 5.61 & 28 & $36.11 \pm 0.43$ & 2.30 & 6.37 \\
\hline
\end{tabular}

Nasal index

\begin{tabular}{l|rccc|cccc}
\hline & \multicolumn{4}{|c|}{ o } & \multicolumn{4}{c}{ o } \\
\hline & $\mathrm{n}$ & $\mathrm{M} \pm \mathrm{m}$ & $\sigma$ & $\mathrm{v}$ & $\mathrm{n}$ & $\mathrm{M} \pm \mathrm{m}$ & $\sigma$ & $\mathrm{v}$ \\
\hline Hoklo Chinese & 218 & $60.87 \pm 0.32$ & 4.77 & 7.83 & 83 & $61.19 \pm 0.44$ & 4.05 & 6.62 \\
Hakka Chinese & 101 & $62.96 \pm 0.51$ & 5.10 & 8.10 & 33 & $63.13 \pm 0.77$ & 4.43 & 7.02 \\
Atayals & 32 & $61.47 \pm 0.82$ & 4.63 & 7.54 & 51 & $60.61 \pm 0.51$ & 3.67 & 6.05 \\
Amis & 29 & $65.20 \pm 1.01$ & 5.42 & 8.31 & 28 & $62.99 \pm 0.97$ & 5.11 & 8.11 \\
\hline
\end{tabular}


(61. $61 \mathrm{~mm})$ よりかなり大きく，漢族はタイ ヤル族 $(60.34 \mathrm{~mm})$, アミ族 $(60.33 \mathrm{~mm})$ よ りかなり大きい。平埔族 $(51.33 \mathrm{~mm})$ は小き い。

女性の種族間の傾向は男性と同様である。 鼻巾：福建人男性 $(37.99 \mathrm{~mm})$ は広東人

Fig. 6.

Nasal height

Hoklo Chinese

Hakka Chinese

Atayls

Amis

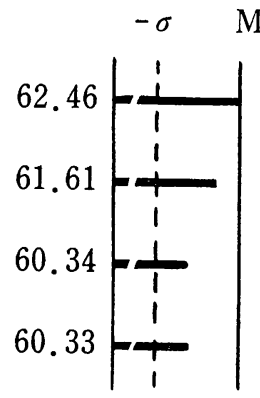

(38.67 mm) より かなり小さく，タイヤル族 $(37.00 \mathrm{~mm})$ はアミ族 $(39.38 \mathrm{~mm})$ より明ら かに小さい。

女性でも同様のととがいえる。

平埔族（男性 $40.39 \mathrm{~mm}$, 文性 $37.56 \mathrm{~mm}$ ) はかなり大きい。

Nasal index

Nasal breadth

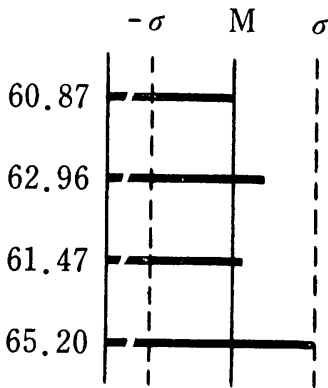

Table 18. Ear length

\begin{tabular}{l|rccc|cccc}
\hline & \multicolumn{4}{|c|}{$\delta$} & \multicolumn{4}{c}{ 울 } \\
\hline & $\mathrm{n}$ & $\mathrm{M} \pm \mathrm{m}$ & $\sigma$ & $\mathrm{v}$ & $\mathrm{n}$ & $\mathrm{M} \pm \mathrm{m}$ & $\sigma$ & $\mathrm{v}$ \\
\hline Hoklo Chinese & 223 & $63.98 \pm 0.29$ & 4.38 & 6.84 & 85 & $61.05 \pm 0.44$ & 4.06 & 6.65 \\
Hakka Chinese & 103 & $64.52 \pm 0.42$ & 4.25 & 6.58 & 34 & $61.47 \pm 0.63$ & 3.66 & 5.96 \\
Atayals & 32 & $64.50 \pm 0.76$ & 4.29 & 6.65 & 50 & $61.28 \pm 0.54$ & 3.83 & 6.25 \\
Amis & 30 & $61.93 \pm 0.81$ & 4.43 & 7.15 & 28 & $60.25 \pm 0.83$ & 4.40 & 7.31 \\
\hline
\end{tabular}

Ear breadth

\begin{tabular}{l|rccc|cccc}
\hline & \multicolumn{4}{|c|}{ o } & \multicolumn{4}{c}{ o } \\
\cline { 2 - 9 } & $\mathrm{n}$ & $\mathrm{M} \pm \mathrm{m}$ & $\sigma$ & $\mathrm{v}$ & $\mathrm{n}$ & $\mathrm{M} \pm \mathrm{m}$ & $\sigma$ & $\mathrm{v}$ \\
\hline Hoklo Chinese & 222 & $31.86 \pm 0.15$ & 2.28 & 7.15 & 85 & $29.49 \pm 0.25$ & 2.27 & 7.70 \\
Hakka Chinese & 104 & $32.49 \pm 0.22$ & 2.23 & 6.86 & 35 & $30.34 \pm 0.36$ & 2.13 & 7.01 \\
Atayals & 32 & $33.06 \pm 0.32$ & 1.81 & 5.48 & 50 & $30.92 \pm 0.31$ & 2.16 & 6.97 \\
Amis & 30 & $31.93 \pm 0.28$ & 1.51 & 4.72 & 28 & $30.43 \pm 0.38$ & 2.01 & 6.60 \\
\hline
\end{tabular}

Ear index

\begin{tabular}{l|rccc|cccc}
\hline & \multicolumn{4}{|c|}{ o } & \multicolumn{4}{c}{ o } \\
\hline & $\mathrm{n}$ & $\mathrm{M} \pm \mathrm{m}$ & $\sigma$ & $\mathrm{v}$ & $\mathrm{n}$ & $\mathrm{M} \pm \mathrm{m}$ & $\sigma$ & $\mathrm{v}$ \\
\hline Hoklo Chinese & 219 & $49.98 \pm 0.28$ & 4.08 & 8.16 & 83 & $48.57 \pm 0.36$ & 3.25 & 6.68 \\
Hakka Chinese & 103 & $50.46 \pm 0.36$ & 3.65 & 7.24 & 33 & $49.75 \pm 0.49$ & 2.83 & 5.70 \\
Atayals & 32 & $51.37 \pm 0.50$ & 2.82 & 5.48 & 49 & $50.54 \pm 0.43$ & 3.00 & 5.94 \\
Amis & 30 & $51.73 \pm 0.60$ & 3.28 & 6.34 & 28 & $50.69 \pm 0.77$ & 4.07 & 8.04 \\
\hline
\end{tabular}


鼻高巾指数：福建人男性（60.87）は広東人 族（34.76 mm）はかなり大きい。

(62.96) より小さく,タイャル族 (61.47) は アミ族（65.20）より小さい。アミ族は漢族よ りあ大きい。アミ族の鼻巾の大きい特性が示さ れる。平埔族（78.56）はいちじるしく大きい。 女性でも広東人 (63.13), アミ族（62.99） は大きい。

19) 耳長, 耳币, 耳指数（Tab. 18）

耳長：福建人男性 $(63.98 \mathrm{~mm})$ と広東人 $(64.52 \mathrm{~mm})$, タイヤル族 $(64.50 \mathrm{~mm})$ との 差はみとめられず，アミ族 $(61.93 \mathrm{~mm})$ はか なり小さい。平埔族 $(63.49 \mathrm{~mm})$ は福建人ら に近い。

女性では漢, 高山, 平埔の諸族が近い。

耳巾：福建人男性 $(31.86 \mathrm{~mm})$ は広東人 $(32.49 \mathrm{~mm})$ より，アミ族 $(31.93 \mathrm{~mm})$ は夕 イヤル族 $(33.06 \mathrm{~mm})$ よりかなり小さい。た だし，漢族と高山族との差は明膫でない。平埔
女性における種族差は明瞭でなく, 平埔族 (32.86 mm) はかなり大きい。

耳指数：福建人男性 (49.98) は広東人 (50.46) よりわずかに小さく,漢族はタイヤル族(51.37) やアミ族（51.73）よりかなり小さい。平埔族 （54.74）は大きい。

女性でも福建人は広東人より，また漢族は高 山族より小さいようである。

顔部のまとめ

漢族は高山族にくらべて煩骨弓巾, 眼内角巾, 鼻高等の測度が大きく，種族差を示すようであ り, 福建人は広東人にくらべて, 煩骨弓巾, 下 顎角巾, 容貌顔面高, 鼻巾, 耳巾での值は小さ い傾向をみとめる。鼻高は福建人のほうが大き いようである。

指数では漢族の頭顔指数, 下顎指数, 容貌顔 面指数, 耳指数が高山族よりむしろ小さく, 福

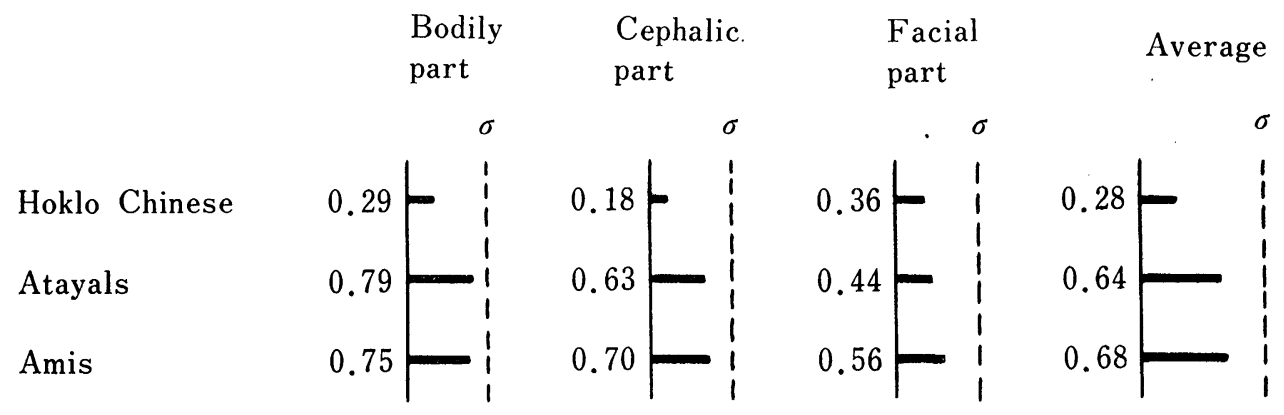

Racial mean relative deviations from the Atayals.

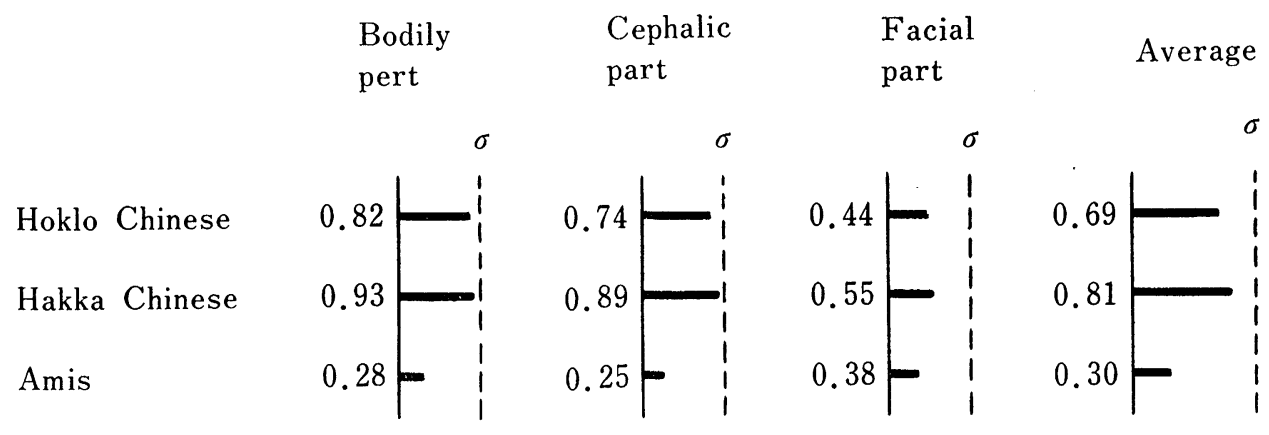


建人の頭顔指数, 䙹指数, 耳指数は広東人より 小さいようである。

アミ族のロ鼻巾がともに大きく, 耳長, 耳巾はむしろ小さい值を示す。

IV) 平均偏差比による類似度の検討 (Fig. 7) 平均偏差比法 ${ }^{-1}-\Sigma \frac{\left|M_{1}-M_{2}\right|}{\rho_{1}}$ によって基準集 団と比較集団との類似度を推定したい。使用し た項目は次のとおりである。

体部：身長, 下肢長, 身幹長, 比下肢長, 比 軀幹長, 比上肢長, 比肩峰巾, 比骨盤巾。

頭部：頭長, 頚巾, 頭耳高, 頭長巾指数, 頭 長高指数, 頭巾高指数。

顔部：煩骨弓币, 容貌顔面高, 舀高, 畀巾, 容貌顔面指数, 鼻高巾指数。

男性よりえた測度, 指数の偏差比を体部, 頭 部, 顔部ごとにまとめ, 平均偏差比を算出し て, 各部の特性を数量的に比較し,さらに 3 部 を総合して種族間の類似度を検討した。

福建人基準：体部に おいて 福建人 と広東人 (0.29) との差は, タイャル族 (0.79) やアミ 族 (0.75) より小さく, 頭部でも広東人 $(0.18)$ との差は小さく，タイヤル族 (0.63), アミ族 （0.70）とは相異している。顔部においては広 東人 $(0.36)$, タイヤル族 $(0.44)$, アミ族 $(0.56)$ との差は，体部や頭部におけるほど種族差が目 立たない。総合してみると広東人 $(0.28)$ が近 く,タイヤル族 (0.64) やアミ族 (0.68) は遠 い。

タイヤル族基準：体部においてタイヤル族 は, 福建人 (0.82) や広東人 (0.93) とはなれ, アミ族 $(0.28)$ とは近い。頭部でも同様の関係 がみられた。顔部では福建人 (0.44), 広東人 (0.55), アミ族 (0.38) との差に目立ったひ らきがない。総合してみると, 福建人 (0.69), 広東人 $(0.81)$ は，はなれており,アミ族 $(0.30)$ は近似している。

総括

漢族と高山族の比較
身長においては漢族が高山族よりかなり大き いが，金関は，アミ族の身長が漢族に近く，ま た，黄は，アミ族の地方差が少ないと報告して いる。

軀幹長, 比監幹長では, 漢族の值が高山族の それより大きいが，比較に使用したデーターの 比躲幹長ではこの傾向がみとめられない。

漢族の頭巾が大きく, 従って頭長巾指数の大 きいととは比較資料であみとめられる。

頭耳高は他の報告との比較に注意が必要であ り, 福建人（忽那ら）の $120.8 \mathrm{~mm}$ (男性) や, アミ族（黄）の $120.30 \mathrm{~mm}$ (男性) は極端に小 さいようである。

漢族の煩骨弓巾は高山族より大きいが，比較 群である福建人（忽那ら）の男性 $(136.1 \mathrm{~mm}$ ) はかなり小さく, 測定法の相違に起因すると考 えられる。また比較群の漢族と高山族との差は みとめられない。

眼内角巾, 鼻高は比較群であ漢族は大きい。 鼻高は形態顔面高の種族差と平行している。

福建人と広東人

広東人は福建人にくらべて, 身長, 稫幹長, 肩峰巾, 骨盤巾, 頭長, 頭巾, 頓骨弓巾, 下顎 角巾, 容貌顔面高, 䁷巾, 耳巾等がかなり大き い。福建人は鼻高がやや広東人よりまさってい るが, 福建人の体形が広東人にくらべて一般に 小さいととを示している。忽那らの福建人は頭 長, 頭耳高, 稫幹の諸径において広東人より小 さく, 顔面高と鼻高は逆に広東人より大きいと 報告している。結局, 広東人が福建人より体つ きの大きいととを指摘している。

\section{タイヤル族とアミ族}

タイヤル族は身長, 下肢長, 骨盤门, 頭長, 容 貌顔面高, 口巾,鼻巾がアミ族より小さい。耳長 , 耳巾はタイヤル族の方が大きいが, KANDA, et al.,（1967）はアミ族の耳巾の大きいととを 報告している。陳（1960）は太巴塱アミ族の調 查によって, アミ族が漢, 平埔族に近く, タイ ヤル族とは疎遠な関係を指摘している。また張 
は,タイヤル族の地方差の少ないことを報告し ている。

平埔族と身体的に近い種族は見当らず（劉 1960），本報告の種族との関係も明確でない。

\section{むすび}

1969 年, 台湾各地で 調査した 福建人, 広東 人, タイヤル族, アミ族の身体的特徽は次の如 くである。

(1)漢族（福建人, 広東人) は高山族（タイヤ ル族，アミ族）より計測学的にまさっている。 漢族は身長, 稫幹長, 頭巾, 頭耳高, 頓骨弓巾, 眼内角巾, 鼻高においてまさっている。

(2)福建人は広東人にくらべて体部, 頭部, 顔 部での值がおとっている。その項目は次の如く である：身長, 軀幹長, 肩峰巾, 骨盤巾, 頭部 三主径, 煩骨弓巾, 下顎角巾, 容貌顔面高, 鼻 巾，耳巾である。

(3)イヤル族の身長, 下肢長, 骨盤巾, 頭長, ロ巾，鼻巾はアミ族より小さい。
この調査の実施にあたり，で尽力下さった， 台湾大学の余錦泉教授, 蔡錫圭副教授, 台中医 学院の蔡浬淋教授をはじめ, 徐傍興外科院長, 李芳樺医学博士, 李昭亭氏ならびに電光牌公司 の各位に深く謝意を表します。

\section{文献}

張 児雄, 1960 : 台湾花蓮県秀林郷秀林村 A tayal 族 の人類学的研究, 人類学研究, $7: 685-944$.

陳 烟宗, 1960 ：台湾花蓮県太巴犋 Ami 族の人類学 的研究, 人類学研究, $7: 753-781$.

黄 紹堂, 1960 : 台湾花蓮県里漏 Ami 族の人類学的 研究, 人類学研究, $7: 782-812$.

金関丈夫, 1952 ：台湾居住民族を中心とした東亜諸民 族の人類学, 福岡医学雑誌, $43: 1-13$.

KANDA, S. et al., 1967, A racial morphology of auricles. Med. J. Osaka Univ., 17;211-221.

忽那将愛・柳井新平, 1943 ：福建系台湾人の生体計測, 台湾医誌, $42: 335-344$.

劉 堂坤, 1960 : 台南県吉具要平埔族 の 生体学的研 究, 人類学研究, $7: 259-290$.

山下静一, 1940 : 広東系台湾人の生体人類学的研究, 台湾医誌，39：1739-1824.

(昭和49年12月 4 日受付) 


\title{
Anthropological Studies on the Inhabitants in Formosa Somatometries on the Hoklo and Hakka Chinese and the Atayals and Amis
}

\author{
Sanae KANDA \\ Department of Anatomy, Hyogo College of Medicine
}

In 1969, Anthropological data on the four groups in Formosa were collected by the late Prof. Mototsugu Kohama. The groups were Hoklo (224 males, 86 females) and Hakka Chinese (104 males, 35 females), and the Atayals (32 males, 51 females) and the Amis (30 males, 28 females) of the Formosan aboriginals The Martin's methods for measurements were applied on stature, standing heights to tragion, acromiale, suprasternale, dactylion and iliospinale ant., cephalic length, cephalic breadth, bizygomatic breadth, bigonial breadth, physiognomic facial height, morphologic facial height I (from supraorbitale to gnathion), nasal height I and II (from the most retreated point of nose in mediansagittal plane to subnasale), nasal breadth, ear length and ear breadth. Arm length, trunk length and cephalic height were calculated from the above measurements.

The following results were indicated;

1) Hoklo and Hakka Chinese were larger than the Atayals and Amis in anthropological measurements. The Chinese were larger than the Formosan aboriginals in the following items: Stature, trunk length, cephalic breadth, cephalic height, bizygomatic breadth, intercanthic breadth and nasal height.

2) The Hoklo Chinese were smaller in physical status than the Hakka Chinese. The Hoklo Chinese were smaller than the Hakka Chinese in the following items; Stature, trunk length, biacromial breadth, pelvic breadth, cephalic length, cephalic breadth, cephalic height, bizygomatic breadth, bigonial breadth, physiognomical facial height, nasal breadth and ear breadth.

3) The Atayals were smaller in stature, leg length, pelvic breadth, cephalic length, mouth breadth and nasal breadth than those of the Amis. 
Hoklo Chinese

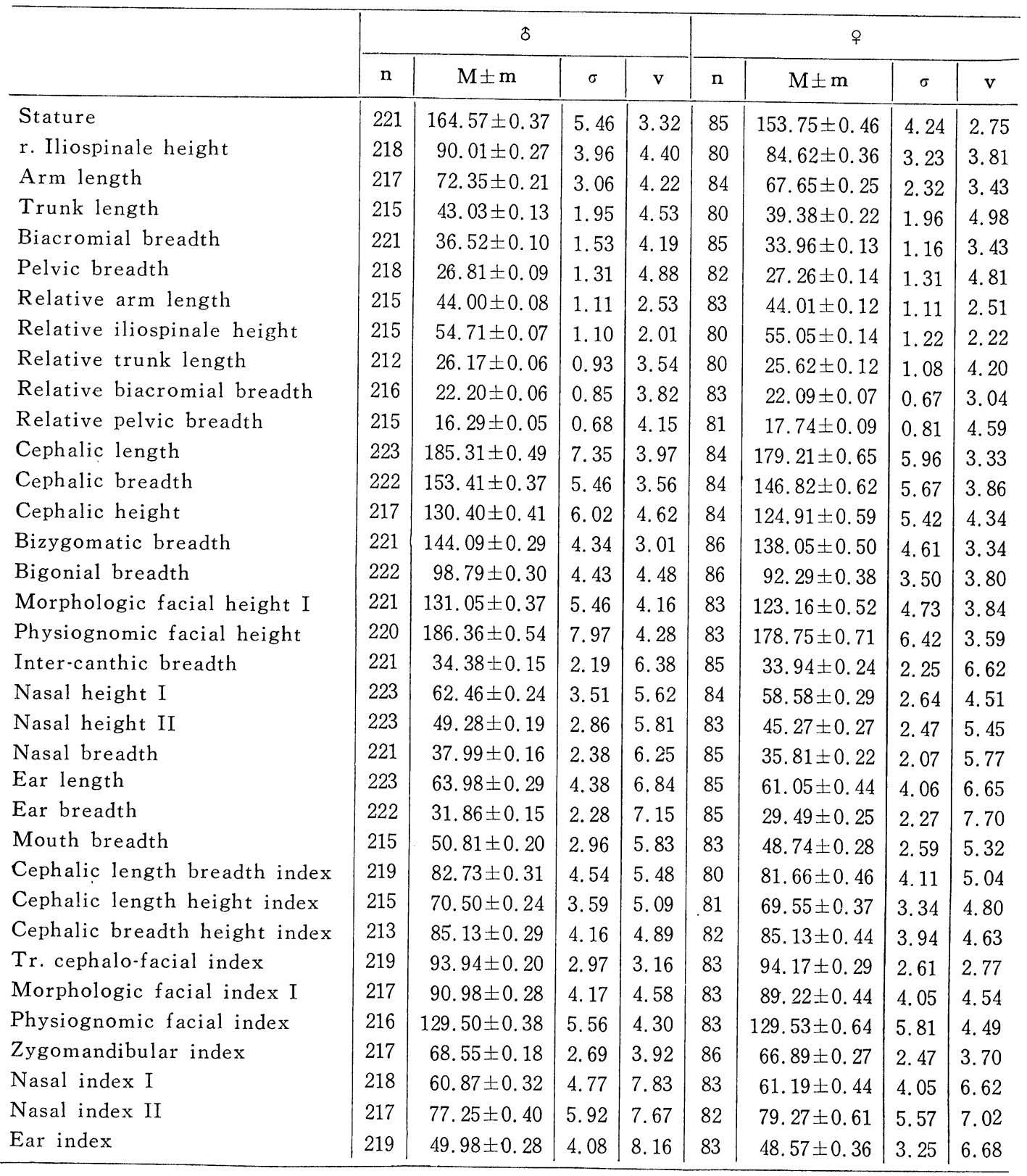


Hakka Chinese

\begin{tabular}{|c|c|c|c|c|c|c|c|c|}
\hline & \multicolumn{4}{|c|}{$\delta$} & \multicolumn{4}{|c|}{ q } \\
\hline & $\mathrm{n}$ & $\mathrm{M} \pm \mathrm{m}$ & $\sigma$ & $\mathbf{v}$ & $\mathrm{n}$ & $\mathrm{M} \pm \mathrm{m}$ & $\sigma$ & $\mathbf{v}$ \\
\hline Stature & 104 & $166.34 \pm 0.54$ & 5.50 & 3.31 & 34 & $155.11 \pm 0.87$ & 5.07 & 3.27 \\
\hline r. Iliospinale height & 103 & $90.68 \pm 0.38$ & 3.82 & 4.21 & 33 & $84.68 \pm 0.61$ & 3.51 & 4.15 \\
\hline Arm length & 100 & $72.69 \pm 0.30$ & 2.98 & 4.10 & 34 & $67.89 \pm 0.43$ & 2.51 & 3.70 \\
\hline Trunk length & 101 & $43.97 \pm 0.20$ & 1.98 & 4.50 & 33 & $40.70 \pm 0.46$ & 2.65 & 6.50 \\
\hline Biacromial breadth & 104 & $37.46 \pm 0.17$ & 1.74 & 4.65 & 33 & $34.47 \pm 0.20$ & 1.15 & 3.34 \\
\hline Pelvic breadth & 103 & $27.40 \pm 0.13$ & 1.33 & 4.86 & 34 & $27.65 \pm 0.24$ & 1.39 & 5.01 \\
\hline Relative arm length & 99 & $43.76 \pm 0.11$ & 1.09 & 2.50 & 33 & $43.68 \pm 0.17$ & 1.00 & 2.30 \\
\hline Relative iliospinale height & 102 & $54.53 \pm 0.10$ & 1.04 & 1.90 & 32 & $54.42 \pm 0.28$ & 1.57 & 2.88 \\
\hline Relative trunk length & 100 & $26.41 \pm 0.10$ & 0.99 & 3.75 & 32 & $26.16 \pm 0.24$ & 1.36 & 5.21 \\
\hline Relative biacromial breadth & 103 & $22.56 \pm 0.08$ & 0.86 & 3.82 & 32 & $22.17 \pm 0.16$ & 0.90 & 4.08 \\
\hline Relative pelvic breadth & 103 & $16.48 \pm 0.07$ & 0.69 & 4.18 & 33 & $17.79 \pm 0.16$ & 0.90 & 5.06 \\
\hline Cephal & 104 & $187.16 \pm 0.64$ & 6.48 & 3.46 & 35 & $180.37 \pm 1.01$ & 5.96 & 3.30 \\
\hline Cephalic b & 103 & $155.01 \pm 0.56$ & 5.67 & 3.66 & 35 & $147.06 \pm 0.78$ & 4.59 & 3.12 \\
\hline Cephalic height & 102 & $131.22 \pm 0.72$ & 7.29 & 5.56 & 34 & $124.91 \pm 0.94$ & 5.47 & 4.38 \\
\hline Bizygomatic breadth & 104 & $146.78 \pm 0.51$ & 5.15 & 3.51 & 34 & $140.59 \pm 0.76$ & 4.43 & 3.15 \\
\hline Bigonial breadth & 104 & $100.56 \pm 0.44$ & 4.45 & 4.43 & 34 & $93.21 \pm 0.70$ & 4.07 & 4.37 \\
\hline Morphologic faci & 102 & $132.29 \pm 0.53$ & 5.36 & 4.05 & 35 & $123.91 \pm 0.99$ & 5.88 & 4.74 \\
\hline ic facial he & 99 & $190.32 \pm 0.85$ & 8.49 & 4.46 & 35 & $180.06 \pm 1.14$ & 6.74 & 3.74 \\
\hline Inter-canthic bre & 103 & $34.30 \pm 0.26$ & 2.59 & 7.56 & 35 & $33.40 \pm 0.35$ & 2.05 & 6.13 \\
\hline Nasal height I & 104 & $61.61 \pm 0.33$ & 3.36 & 5.45 & 33 & $58.21 \pm 0.45$ & 2.57 & 4.42 \\
\hline Nasal height II & 104 & $49.28 \pm 0.30$ & 3.10 & 6.28 & 34 & $44.41 \pm 0.45$ & 2.63 & 5.92 \\
\hline Nasal breadth & 103 & $38.67 \pm 0.28$ & 2.82 & 7.30 & 35 & $37.03 \pm 0.51$ & 2.99 & 8.06 \\
\hline Ear length & 103 & $64.52 \pm 0.42$ & 4.25 & 6.58 & 34 & $61.47 \pm 0.63$ & 3.66 & 5.96 \\
\hline Ear breadth & 104 & $32.49 \pm 0.22$ & 2.23 & 6.86 & 35 & $30.34 \pm 0.36$ & 2.13 & 7.01 \\
\hline Mouth breadth & 99 & $51.47 \pm 0.28$ & 2.75 & 5.33 & 35 & $50.57 \pm 0.48$ & 2.83 & 5.60 \\
\hline Cephalic length breadth index & 103 & $82.94 \pm 0.45$ & 4.60 & 5.55 & 35 & $81.60 \pm 0.58$ & 3.44 & 4. 22 \\
\hline Cephalic length height index & 101 & $70.00 \pm 0.36$ & 3.65 & 5.22 & 34 & $69.40 \pm 0.68$ & 3.96 & 5.71 \\
\hline Cephalic breadth height index & 100 & $84.29 \pm 0.41$ & 4.08 & 4.84 & 33 & $85.49 \pm 0.66$ & 3.80 & 4. 45 \\
\hline Tr. cephalo-facial index & 102 & $94.71 \pm 0.26$ & 2.58 & 2.73 & 34 & $95.50 \pm 0.46$ & 2.70 & 2.83 \\
\hline Morphologic facial index I & 102 & $90.14 \pm 0.41$ & 4.09 & 4.54 & 34 & $88.02 \pm 0.81$ & 4.75 & 5.40 \\
\hline Physiognomic facial index & 98 & $129.86 \pm 0.63$ & 6.21 & 4.78 & 34 & $127.86 \pm 1.03$ & 6.00 & 4.69 \\
\hline Zygomandibular index & 102 & $68.55 \pm 0.27$ & 2.70 & 3.94 & 34 & $66.31 \pm 0.40$ & 2.33 & 3.51 \\
\hline Nasal index I & 101 & $62.96 \pm 0.51$ & 5.10 & 8.10 & 33 & $63.13 \pm 0.77$ & 4.43 & 7.02 \\
\hline Nasal index II & 100 & $78.93 \pm 0.60$ & $\overline{6.02}$ & 7.63 & 34 & $83.08 \pm 1.13$ & 6.62 & 7.96 \\
\hline Ear index & 103 & $50.46 \pm 0.36$ & 3.65 & 7.24 & 33 & $49.75 \pm 0.49$ & 2.83 & 5.70 \\
\hline
\end{tabular}


Atayals

\begin{tabular}{|c|c|c|c|c|c|c|c|c|}
\hline & \multicolumn{4}{|c|}{ 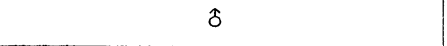 } & \multicolumn{4}{|c|}{ q } \\
\hline & $\mathrm{n}$ & $\mathrm{M} \pm \mathrm{m}$ & $\sigma$ & $\mathrm{v}$ & $\mathrm{n}$ & $\mathrm{M} \pm \mathrm{m}$ & $\sigma$ & $\mathrm{v}$ \\
\hline Stature & 32 & $160.39 \pm 1.02$ & 5.78 & 3.60 & 50 & $152.66 \pm 0.62$ & 4.37 & 2.86 \\
\hline r. Iliospinale height & 32 & $89.06 \pm 0.74$ & 4.18 & 4.70 & 50 & $85.82 \pm 0.44$ & 3.13 & 3.65 \\
\hline Arm length & 32 & $72.33 \pm 0.55$ & 3.10 & 4.29 & 51 & $68.72 \pm 0.38$ & 2.69 & 3.91 \\
\hline Trunk length & 32 & $41.22 \pm 0.34$ & 1.95 & 4.73 & 50 & $38.07 \pm 0.26$ & 1.83 & 4.81 \\
\hline Biacromial breadth & 31 & $37.47 \pm 0.24$ & 1.31 & 3.51 & 50 & $33.73 \pm 0.19$ & 1.31 & 3.88 \\
\hline Pelvic breadth & 32 & $26.63 \pm 0.20$ & 1.16 & 4.34 & 51 & $27.08 \pm 0.18$ & 1.30 & 4.81 \\
\hline Relative arm length & 31 & $45.23 \pm 0.16$ & 0.90 & 1.99 & 50 & $45.06 \pm 0.16$ & 1.12 & 2. 48 \\
\hline Relative iliospinale height & 32 & $55.51 \pm 0.17$ & 0.99 & 1.78 & 49 & $56.26 \pm 0.14$ & 0.99 & 1.76 \\
\hline Relative trunk length & 32 & $25.70 \pm 0.17$ & 0.98 & 3.81 & 49 & $24.96 \pm 0.16$ & 1.09 & 4.37 \\
\hline Relative biacromial breadth & 31 & $23.43 \pm 0.15$ & 0.82 & 3.48 & 49 & $22.11 \pm 0.11$ & 0.79 & 3.58 \\
\hline Relative pelvic breadth & 32 & $16.61 \pm 0.11$ & 0.61 & 3.70 & 50 & $17.77 \pm 0.11$ & 0.75 & $4.2 ; 4$ \\
\hline Cephalic length & 32 & $185.47 \pm 0.92$ & 5.18 & 2.79 & 51 & $180.43 \pm 0.79$ & 5.66 & 3.14 \\
\hline Cephalic breadth & 32 & $146.88 \pm 0.86$ & 4.88 & 3.33 & 51 & $141.41 \pm 0.61$ & 4.33 & 3.06 \\
\hline Cephalic height & 32 & $125.34 \pm 0.87$ & 4.94 & 3.94 & 50 & $121.36 \pm 0.77$ & 5.42 & 4. 47 \\
\hline Bizygomatic bread & 32 & $141.50 \pm 0.85$ & 4.80 & 3.39 & 51 & $135.02 \pm 0.50$ & 3.58 & 2.65 \\
\hline Bigonial breadth & 32 & $98.34 \pm 0.69$ & 3.87 & 3.94 & 51 & $92.10 \pm 0.43$ & 3.09 & 3.35 \\
\hline Morphologic facial height I & 30 & $127.50 \pm 1.00$ & 5.46 & 4.28 & 49 & $119.61 \pm 0.80$ & 5.60 & 4.68 \\
\hline Physiognomic facial height & 31 & $188.48 \pm 1.56$ & 8.69 & 4.61 & 49 & $178.47 \pm 1.19$ & 8.32 & 4.66 \\
\hline Inter-canthic breadth & 32 & $33.34 \pm 0.35$ & 1.98 & 5.93 & 51 & $32.49 \pm 0.28$ & 1.98 & 6.11 \\
\hline Nasal height I & 32 & $60.34 \pm 0.59$ & 3.32 & 5.50 & 51 & $56.28 \pm 0.34$ & 2.46 & 4.37 \\
\hline Nasal height II & 32 & $46.91 \pm 0.53$ & 2.99 & 6.37 & 50 & $43.76 \pm 0.24$ & 1.70 & 3.88 \\
\hline Nasal breadth & 32 & $37.00 \pm 0.39$ & 2.20 & 5.95 & 51 & $34.08 \pm 0.29$ & 2.08 & 6.09 \\
\hline Ear length & 32 & $64.50 \pm 0.76$ & 4.29 & 6.65 & 50 & $61.28 \pm 0.54$ & 3.83 & 6.25 \\
\hline Ear breadth & 32 & $33.06 \pm 0.32$ & 1.81 & 5.48 & 50 & $30.92 \pm 0.31$ & 2.16 & 6.97 \\
\hline Mouth breadth & 31 & $50.97 \pm 0.42$ & 2.36 & 4.63 & 48 & $48.65 \pm 0.31$ & 2.13 & 4.38 \\
\hline Cephalic length bre & 32 & $79.27 \pm 0.68$ & 3.86 & 4.87 & 51 & $78.44 \pm 0.47$ & 3.33 & 4.24 \\
\hline Cephalic length he & 31 & $67.33 \pm 0.51$ & 2.85 & 4.23 & 49 & $67.12 \pm 0.46$ & 3.24 & 4.82 \\
\hline Cephalic breadth height index & 32 & $85.41 \pm 0.71$ & 4.02 & 4.71 & 50 & $85.84 \pm 0.61$ & 4.31 & 5.02 \\
\hline Tr. cephalo-facial index & 32 & $96.37 \pm 0.43$ & 2.44 & 2.53 & 50 & $95.67 \pm 0.35$ & 2.49 & 2.60 \\
\hline Morphologic facial index I & 30 & $90.16 \pm 0.82$ & 4.48 & 4.96 & 49 & $88.61 \pm 0.63$ & 4. 43 & 5.00 \\
\hline Physiognomic facial index & 31 & $133.06 \pm 1.03$ & 5.71 & 4. 29 & 49 & $132.24 \pm 1.01$ & 7.10 & 5.37 \\
\hline Zygomandibular index & 32 & $69.53 \pm 0.43$ & 2.43 & 3.50 & 50 & $68.10 \pm 0.34$ & 2.43 & 3.57 \\
\hline Nasal index I & 32 & $61.47 \pm 0.82$ & 4.63 & 7.54 & 51 & $60.61 \pm 0.51$ & 3.67 & 6.05 \\
\hline Nasal index II & 32 & $79.11 \pm 1.05$ & 5.93 & 7.50 & 49 & $78.25 \pm 0.57$ & 4.02 & 5.14 \\
\hline Ear index & 32 & $51.37 \pm 0.50$ & 2.82 & 5.48 & 49 & $50.54 \pm 0.43$ & 3.00 & 5.94 \\
\hline
\end{tabular}


Amis

\begin{tabular}{|c|c|c|c|c|c|c|c|c|}
\hline & \multicolumn{4}{|c|}{$\delta$} & \multicolumn{4}{|c|}{ 우 } \\
\hline & $\mathrm{n}$ & $\mathrm{M} \pm \mathrm{m}$ & $\sigma$ & $\mathrm{v}$ & $\mathrm{n}$ & $\mathrm{M} \pm \mathrm{m}$ & $\sigma$ & $\mathrm{v}$ \\
\hline Stature & 30 & $162.44 \pm 0.88$ & 4.84 & 2.98 & 27 & $152.00 \pm 0.63$ & 3.25 & 2.14 \\
\hline r. Iliospinale height & 30 & $90.62 \pm 0.65$ & 3.56 & 3.93 & 27 & $84.92 \pm 0.50$ & 2.59 & 3.05 \\
\hline Arm length & 30 & $73.14 \pm 0.49$ & 2.68 & 3.66 & 27 & $66.91 \pm 0.41$ & 2.16 & 3.22 \\
\hline Trunk length & 30 & $41.04 \pm 0.33$ & 1.83 & 4.46 & 27 & $38.22 \pm 0.28$ & 1.46 & 3.83 \\
\hline Biacromial breadth & 30 & $37.49 \pm 0.36$ & 1.97 & 5.24 & 28 & $34.41 \pm 0.26$ & 1.36 & 3.94 \\
\hline Pelvic breadth & 30 & $27.22 \pm 0.27$ & 1. 49 & 5.48 & 28 & $27.48 \pm 0.23$ & 1.24 & 4.52 \\
\hline Relative arm length & 30 & $45.03 \pm 0.20$ & 1.08 & 2.41 & 27 & $44.01 \pm 0.17$ & 0.89 & 2. 01 \\
\hline Relative iliospinale height & 29 & $55.59 \pm 0.19$ & 1.02 & 1.84 & 27 & $55.86 \pm 0.18$ & 0.91 & 1.63 \\
\hline Relative trunk length & 30 & $25.27 \pm 0.17$ & 0.95 & 3.76 & 27 & $25.15 \pm 0.18$ & 0.94 & 3. 72 \\
\hline Relative biacromial breadth & 30 & $23.07 \pm 0.16$ & 0.88 & 3.80 & 27. & $22.59 \pm 0.15$ & 0.76 & 3.36 \\
\hline Relative pelvic breadth & 30 & $16.76 \pm 0.16$ & 0.88 & 5.24 & 27 & $18.00 \pm 0.12$ & 0.61 & 3. 41 \\
\hline Cephalic length & 29 & $188.62 \pm 1.11$ & 5.99 & 3.17 & 28 & $182.43 \pm 1.00$ & 5.30 & 2.90 \\
\hline Cephalic breadth & 30 & $147.37 \pm 1.08$ & 5.90 & 4.01 & 28 & $143.36 \pm 0.73$ & 3.86 & 2.69 \\
\hline Cephalic height & 29 & $126.83 \pm 1.13$ & 6.08 & 4.80 & 27 & $122.89 \pm 1.06$ & 5.49 & 4.46 \\
\hline Bizygomatic breadth & 30 & $142.73 \pm 1.01$ & 5.51 & 3.86 & 28 & $138.18 \pm 0.61$ & 3.23 & 2.34 \\
\hline Bigonial breadth & 30 & $98.77 \pm 0.85$ & 4.66 & 4.72 & 28 & $93.50 \pm 0.75$ & 3.97 & 4.24 \\
\hline Morphologic facial height I & 30 & $130.77 \pm 1.11$ & 6.07 & 4.64 & 28 & $122.57 \pm 1.05$ & 5.53 & 4.51 \\
\hline Physiognomic facial height & 30 & $189.40 \pm 1.54$ & 8.43 & 4.45 & 28 & $182.00 \pm 1.25$ & 6.62 & 3.64 \\
\hline Inter-canthic breadth & 30 & $33.10 \pm 0.42$ & 2.28 & 6.89 & 28 & $32.79 \pm 0.41$ & 2.15 & 6.56 \\
\hline Nasal height I & 30 & $60.33 \pm 0.49$ & 2.70 & 4.47 & 28 & $57.46 \pm 0.58$ & 3.06 & 5.33 \\
\hline Nasal height II & 30 & $46.97 \pm 0.41$ & 2.22 & 4.73 & 28 & $44.04 \pm 0.47$ & 2.49 & 5.65 \\
\hline Nasal breadth & 29 & $39.38 \pm 0.41$ & 2.21 & 5.61 & 28 & $36.11 \pm 0.43$ & 2.30 & 6.37 \\
\hline Ear length & 30 & $61.93 \pm 0.81$ & 4.43 & 7.15 & 28 & $60.25 \pm 0.83$ & 4. 40 & 7.31 \\
\hline Ear breadth & 30 & $31.93 \pm 0.28$ & 1.51 & 4.72 & 28 & $30.43 \pm 0.38$ & 2.01 & 6.60 \\
\hline Mouth breadth & 30 & $53.67 \pm 0.69$ & 3.79 & 7.06 & 27 & $50.15 \pm 0.55$ & 2.88 & 5.74 \\
\hline Cephalic length breadth index & 29 & $78.36 \pm 0.74$ & 3.97 & 5.06 & 28 & $78.64 \pm 0.55$ & 2.91 & 3.70 \\
\hline Cephalic length height index & 28 & $67.50 \pm 0.61$ & 3.20 & 4.75 & 27 & $67.52 \pm 0.57$ & 2.96 & 4.38 \\
\hline Cephalic breadth height index & 29 & $86.20 \pm 0.75$ & 4.05 & 4.70 & 27 & $85.90 \pm 0.84$ & 4.35 & 5.06 \\
\hline Tr. cephalo-facial index & 29 & $96.56 \pm 0.41$ & 2.23 & 2.31 & 28 & $96.42 \pm 0.38$ & 2.01 & 2.08 \\
\hline Morphologic facial index I & 30 & $91.69 \pm 0.79$ & 4.30 & 4.69 & 28 & $88.72 \pm 0.72$ & 3.83 & 4.32 \\
\hline Physiognomic facial index & 30 & $132.83 \pm 1.22$ & 6.66 & 5.01 & 28 & $131.73 \pm 0.82$ & 4.33 & 3.29 \\
\hline Zygomandibular index & 30 & $69.22 \pm 0.48$ & 2.64 & 3.81 & 28 & $67.70 \pm 0.60$ & 3.16 & 4.67 \\
\hline Nasal index I & 29 & $65.20 \pm 1.01$ & 5.42 & 8.31 & 28 & $62.99 \pm 0.97$ & 5.11 & 8.11 \\
\hline Nasal index II & 29 & $83.75 \pm 1.24$ & 6.66 & 7.95 & 28 & $82.27 \pm 1.39$ & 7.34 & 8.92 \\
\hline Ear index & 30 & $51.73 \pm 0.60$ & 3.28 & 6.34 & 28 & $50.69 \pm 0.77$ & 4.07 & 8.04 \\
\hline
\end{tabular}

